
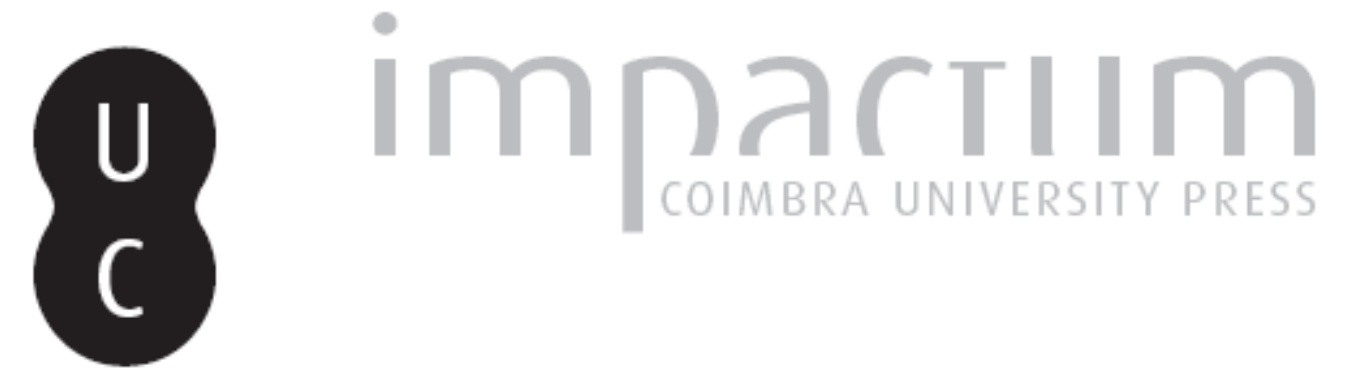

\title{
Para o estudo da alimentação no século XVIII: o agasalho dos prelados no decurso das visitas pastorais
}

\author{
Autor(es): $\quad$ Oliveira, Ricardo Pessa de
}

Publicado por: Centro de História da Sociedade e da Cultura

URL persistente:

URI:http://hdl.handle.net/10316.2/39524

DOI:

DOI:http://dx.doi.org/10.14195/1645-2259_10-1_14

Accessed : $\quad$ 26-Apr-2023 15:21:16

A navegação consulta e descarregamento dos títulos inseridos nas Bibliotecas Digitais UC Digitalis, UC Pombalina e UC Impactum, pressupõem a aceitação plena e sem reservas dos Termos e Condições de Uso destas Bibliotecas Digitais, disponíveis em https://digitalis.uc.pt/pt-pt/termos.

Conforme exposto nos referidos Termos e Condições de Uso, o descarregamento de títulos de acesso restrito requer uma licença válida de autorização devendo o utilizador aceder ao(s) documento(s) a partir de um endereço de IP da instituição detentora da supramencionada licença.

Ao utilizador é apenas permitido o descarregamento para uso pessoal, pelo que o emprego do(s) título(s) descarregado(s) para outro fim, designadamente comercial, carece de autorização do respetivo autor ou editor da obra.

Na medida em que todas as obras da UC Digitalis se encontram protegidas pelo Código do Direito de Autor e Direitos Conexos e demais legislação aplicável, toda a cópia, parcial ou total, deste documento, nos casos em que é legalmente admitida, deverá conter ou fazer-se acompanhar por este aviso.

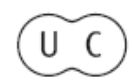




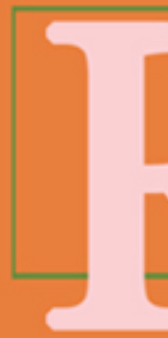

\section{evista de História}

da Sociedade e da

Cultura

\section{Tomo I}

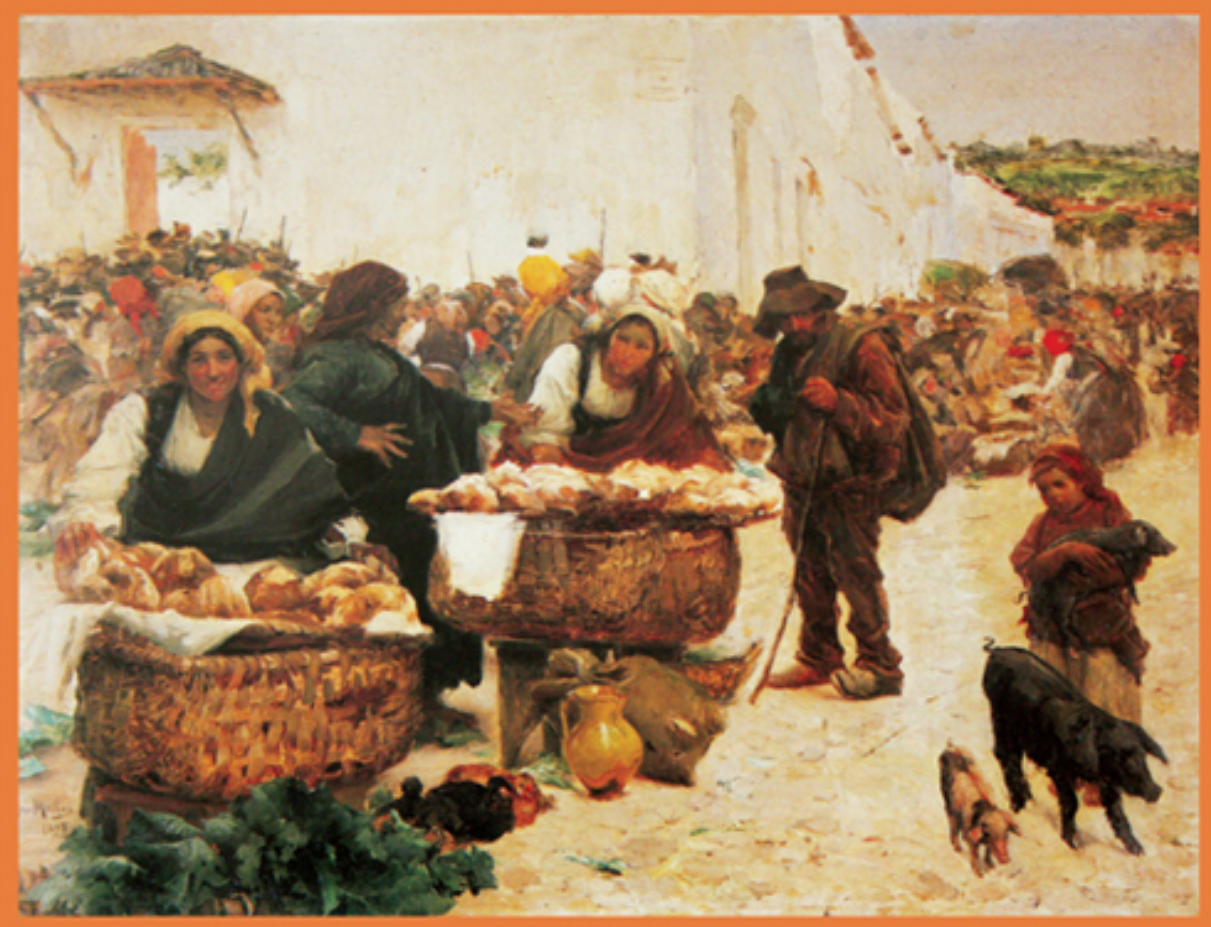

Centro de História da Sociedade e da Cultura Universidade de Coimbra

Coimbra 


\title{
Para o estudo da alimentação no século XVIII: $O$ agasalho dos Prelados no decurso das visitas pastorais
}

\author{
Ricardo Pessa de Oliveira \\ Doutorando em História Moderna - Universidade de Lisboa \\ Bolseiro da Fundação Calouste Gulbenkian \\ ricardo_pessa@sapo.pt \\ Texto recebido em/ Text submitted on: 28/02/2010 \\ Texto aprovado em/ Text approved on: 31/03/2010
}

\section{Resumo/Abstract:}

O exercício das visitas pastorais envolveu a deslocação de comitivas, em alguns casos relativamente extensas. Para sustento e agasalho do séquito foram instituídos tributos. O presente artigo pretende estudar e analisar as procurações recebidas pelos prelados aquando da visita pastoral, partindo do princípio que tal investigação poderá contribuir para a história da alimentação desta elite. Pretendendo verificar mudanças ou uniformidades, o estudo compara procurações havidas nos bispados de Coimbra e da Guarda.

Pastoral visits involved, in some cases, the travelling of large entourages. To ensure that the retinue was fed and clothed, taxes were stipulated. This paper intends to study and analyse the proxies, which the prelates were granted during the pastoral visit, based on the assumption that this research will provide input to the history of this elite's eating habits. In view of identifying differences and similarities, the study compares proxies granted in the bishoprics of Coimbra and Guarda.

Palavras chave/Keywords:

Século XVIII; Visitas Pastorais; Visitadores; Tributos; Alimentação.

18th century; Pastoral Visits; Visitors; Taxes; Food. 
1. O poder jurisdicional da Igreja no que toca à correcção dos desvios tem sido uma das vertentes analisadas sob a perspectiva do disciplinamento social nas diversas confessionalizações ${ }^{1}$. De origem alemã, e sendo inicialmente aplicados à história política, o âmbito destes conceitos foi alargado à história religiosa, tanto mais que as relações entre Estado e Igreja foram marcadas por uma intervenção mútua ${ }^{2}$. A historiografia religiosa ibérica tem centrado a sua atenção sobretudo na acção do Tribunal do Santo Ofício enquanto instituição de normalização social e menos em outras formas de impor modelos comportamentais, tais como os tribunais diocesanos ${ }^{3}$.

A visita pastoral assumiu-se como um dos principais mecanismos de controlo e disciplinamento social ${ }^{4}$. Constituindo um dos deveres primordiais

1 PALOMO, Federico - «Disciplina christiana» Apuntes historiográficos en torno a la disciplina y el disciplinamento social como categorias de la historia religiosa de la alta edad moderna. Cuadernos de Historia Moderna. 18, Madrid (1997) 121-122. Sobre os conceitos de confessionalização e disciplinamento social cf. SCHULZE, Winfried Il concetto di «disciplinamento sociale nella prima età moderna» in Gerhard Oestreich. Annali dell'Instituto Storico Italo-Germanico in Trento, 18, (1992) 371-411; REINHARD, Wolfgang - Disciplinamento sociale, confessionalizzazione, modernizzazione. Un discorso storiografico in PRODI, Paolo and PENUTI, Carla (ed.) - Disciplina dell'anima, Disciplina del Corpo e Disciplina della Società tra Medioevo ed età Moderna. Bolonha: Società Editrice il Mulino, 1994, p. 101-123; SCHILLING, Heinz - Chiese confessionali e disciplinamento sociale. Un bilancio provvisorio della ricerca storica in PRODI, Paolo and PENUTI, Carla (ed.) - Disciplina dell'anima ..., cit., p. 125-160; PROSPERI, Adriano - Tribunali della coscienza. Inquisitori, confessori, missionari. Torino: Einaudi, 1996; PALOMO, Federico - Fazer dos Campos Escolas Excelentes. Os Jesuitas de Évora e as Missões do Interior em Portugal (1551-1630). Lisboa: Fundação Calouste Gulbenkian, Fundação para a Ciência e a Tecnologia, 2003, p. 25-31.

2 PAIVA, José Pedro - El Estado en la Iglesia y la Iglesia en el Estado. Contaminaciones, dependencias y disidencia entre la monarquía y la Iglesia del reino de Portugal (1495-1640). Manuscrits. revista d'història moderna. 25 (2007), 45-57.

3 PALOMO, Federico - «Disciplina christiana ..., cit., p. 122-123.

4 Sobre a visita pastoral em Portugal cf. SANTOS, Eugénio dos - Os Livros das Visitas Pastorais da Região Portuense. Questões e Perspectivas de Abordagem. Revista de História. 2 (1979) 237-244; CARVALHO, Joaquim Ramos de - As Visitas Pastorais e a Sociedade de Antigo Regime. Notas para o estudo de um mecanismo de normalização social. Coimbra: Provas de capacidade científica apresentadas à Faculdade de Letras da Universidade de Coimbra, 1985, exemplar mimeografado; BETHENCOURT, Francisco - As visitas pastorais. Um Estudo de Caso (Entradas, 1572-1593). Revista de História Económica e Social. 19 (1987) 95-122; JOÃO, Luís Inácio - Visitas Pastorais em Leiria e freguesias vizinhas no século XVII. Elementos para o estudo duma situação sócio-religiosa. Lisboa: Dissertação de mestrado em Sociologia Aprofundada e Realidade Portuguesa, apresentada à Faculdade de Ciências Sociais e Humanas da Universidade Nova de Lisboa, 1988, exemplar mimeografado; CARVALHO, Joaquim Ramos de Carvalho, PAIVA, José Pedro - A evolução das visitas pastorais da diocese 
dos antístites, o seu exercício permitia difundir a doutrina da Igreja, fiscalizar o funcionamento das igrejas da diocese e dos seus funcionários, vigiar e ter exacta noção do estado em que se encontrava a diocese e quais as necessidades a serem supridas. A visita pretendia conservar a doutrina, os bons costumes e extirpar as heresias, objectivos que deviam ser atingidos sobretudo por intermédio da advertência ${ }^{5}$. Além do controlo exercido sobre o universo religioso, a visita pastoral servia também como instrumento de controlo sobre a população laica, disciplinando os seus comportamentos ${ }^{6}$. Desta forma a uma função pastoral aliava uma tarefa correctiva, contribuindo

de Coimbra nos séculos XVII e XVIII. Ler História. 15 (1989) 29-41; CARVALHO, Joaquim Ramos de - A Jurisdição Episcopal sobre leigos em matéria de pecados públicos: As visitas pastorais e o comportamento moral das populações portuguesas de Antigo Regime. Revista Portuguesa de História. 24 (1990) 121-163; ENES, Maria Fernanda - Reforma Tridentina e Religião Vivida (os Açores na Época Moderna). Ponta Delgada: Eurosigno Publicações, 1991; PAIVA, José Pedro - Uma instrução aos visitadores do bispado de Coimbra (século XVII?) e os textos regulamentadores das visitas pastorais em Portugal. Revista de História das Ideias. 15 (1993) 637-661; SOARES, António Franquelim Sampaio Neiva - A Arquidiocese de Braga no século XVII. Sociedade e Mentalidades pelas Visitações Pastorais (1550-1700). Braga: Edição do Autor, 1997; PAIVA, José Pedro - As Visitas Pastorais in AZEVEDO, Carlos Moreira (ed.) - História Religiosa de Portugal. vol. II. Lisboa: Círculo de Leitores, 2000, p. 250-255; CARVALHO, Joaquim Ramos de, PAIVA, José Pedro - Visitações in AZEVEDO, Carlos Moreira (ed.) - Dicionário de História Religiosa de Portugal. vol. P-V, Apêndices. Lisboa: Círculo de Leitores, 2001, p. 365-370; LEAL, Bruno - La Crosse et le Bâton. Visites Pastorales et recherche des pécheurs publics dans le diocèse d'Algarve 1630-1750. Paris: Centre Culturel Calouste Gulbenkian, 2004; PALOMO, Federico - A Contra-Reforma em Portugal 1540-1700. Lisboa: Livros Horizonte, 2006, p. 35-38; COSTA, Susana Goulart Viver e Morrer Religiosamente. Ilha de São Miguel. Século XVIII. Ponta Delgada: Instituto Cultural de Ponta Delgada, 2007.

5 CARVALHO, Joaquim Ramos de Carvalho - As Visitas Pastorais e a Sociedade ..., cit., p. 43. "E o fim a que deuem dirigir a sua visitação he, primeyramĕnte plătar boa \& sam doutrina expirpando as herezias, scismas, \& superstições a ella contrarias, conseruar os bons custumes, \& emendar os maos com amestações, repulções, \& castigos conueniětes: ensinar ao pouo o que conuem pera sua saluação, \& incitar os fieis à virtude, paz, \& conformidade, \& fazer tudo o mais que lhe parecer q conuem para proueyto de nossos subditos.”, cf. Constituições Sinodais do Bispado de Coimbra. Coimbra: António de Mariz, 1591, fl. 169v. “[...] \& com boas amoestações accender o povo em charidade, \& amor de Deos, \& do proximo, [...] porque isto muytas vezes se causa mais com boas amoestações \& saudaveis conselhos, \& com remedios brandos \& benignos, que com rigor da pena[...]", cf. Constituições Sinodais do Bispado de Coimbra ..., cit., fl. 170v.

6 Cf. PAIVA, José Pedro - Dioceses e organização eclesiástica in AZEVEDO, Carlos Moreira (ed.) - História Religiosa ..., cit., p. 195; Idem - As Visitas..., cit., p. 250-255. 
para a afirmação da jurisdição do prelado na sua diocese ${ }^{7}$. No carácter judicial da devassa residia a grande diferença entre a visita pastoral portuguesa pós tridentina e as visitas realizadas nos restantes países ${ }^{8}$. Para indagar sobre os pecados públicos eram designadas testemunhas escolhidas entre os paroquianos, através do rol dos confessados. As denúncias constituíam como que um processo inicial que em casos mais graves poderia levar a um processo judicial no auditório episcopal ${ }^{9}$.

Durante o século XVII e primeira metade da centúria seguinte, a periodicidade das visitas pastorais foi, em grande parte das dioceses, bastante elevada, realizando-se quase anualmente ${ }^{10}$. O Concílio de Trento havia incumbido o bispo de, pessoalmente ou fazendo-se representar pelo seu vigário ou por outro ministro competente, visitar todos os anos o seu bispado, "ou que ao menos se acabe de visitar todo dentro de dous annos [...]" sendo que a primeira visita devia ser levada a cabo pelo próprio bispo e "com muito vagar"11. Durante a visita o prelado era auxiliado por várias pessoas ${ }^{12}$. Um manuscrito da Biblioteca Nacional dá a conhecer

7 CARVALHO, Joaquim Ramos de, PAIVA, José Pedro - Visitações..., cit., p. 365. Sobre as questões jurisdicionais cf. CARVALHO, Joaquim Ramos de - A Jurisdição Episcopal..., cit., p. 121-163.

${ }^{8}$ CARVAlHO, Joaquim Ramos de - A Jurisdição Episcopal..., cit., p. 127-132; CARVALHO, Joaquim Ramos de, PAIVA, José Pedro - Visitações..., cit., p. 369.

9 Sobre esta realidade cf. NUNES, João Rocha - Crime e castigo: 'Pecados Publicos' e Disciplinamento Social na Diocese de Viseu (1684-1689). Revista de História da Sociedade e da Cultura. 6 (2006) 177-213.

${ }^{10}$ PAIVA, José Pedro - As visitas..., cit., p. 253. Atendendo ao caso da diocese de Lisboa a periodicidade das visitas pastorais seria também elevada no século XV e primeira metade da centúria seguinte. Os prelados daquela diocese visitavam pessoalmente o seu território pelo menos uma vez no decorrer da sua prelatura, cf. CARVALHO, Joaquim Ramos de, PAIVA, José Pedro - Visitações..., cit., p. 366. Nas ilhas a periodicidade era menor, realidade que se explicaria pela geografia, pela ausência de territórios visitados por outras dignidades e pelo papel de certa substituição desempenhado pelos ouvidores. A ilha de São Miguel apenas foi visitada 18 vezes no período de 1693 a 1812, cf. COSTA, Susana Goulart - Viver e Morrer..., cit., p. 75-80. Sobre este mesmo assunto cf. ENES, Maria Fernanda - Reforma Tridentina..., cit., p.35-37.

${ }^{11}$ ANDRADE, Lucas de - Visita Geral que deve fazer hum Prelado no seu Bispado, apontadas as cousas por que deve perguntar. E o que devem os Parochos preparar para a visita. Lisboa: Oficina de João da Costa, 1673, p. 7-9.

${ }^{12}$ Entre os quais o seu "Mestre de Ceremonias, algum Pregador, \& alguns Confessores, que mandara diante a pregar $\&$ confessar, \& o Mestre de Ceremonias a ensinar, o como se deve preparar para a visita do Prelado, pera que se ache tudo disposto como convem quando chegar àquella Parochia”, cf. ANDRADE, Lucas de - Visita Geral..., cit., p. 25-26 
as comitivas que acompanhavam alguns bispos ${ }^{13}$. Segundo o documento durante a visita pastoral o bispo de Lamego era assistido por 17 pessoas. O número de animais utilizados na deslocação era igualmente elevado, a saber 19. O antístite de Coimbra viajava numa sege puxada por duas bestas, numa comitiva composta por 17 pessoas e 16 bestas. Integravam o séquito o donato, o mordomo, o caudatário, o mestre-de-cerimónias, o meirinho geral, o visitador "logo atrás de Sua Excelência, e se detem 2 e 3 dias por igreja" e o secretário da visita. Além destes seguiam com o séquito duas bestas de carga com almocreve e vários criados. O prelado do Porto, D. João de Sousa, era acompanhado por 28 pessoas, que se faziam transportar por 27 bestas, estando incluídas neste número as de duas liteiras. Auxiliavam o antístite o arcediago de bago, o desembargador secretário da visita, três capelães para os pontificais, sendo que um deles era o mestre-de-cerimónias, e o meirinho geral com dois homens de vara. Além destes fazia-se acompanhar por um cozinheiro e um ajudante de copa, bem como por vários criados e pajens. Mais tarde, D. frei José Maria da Fonseca e Évora, bispo da mesma diocese, na visita que realizou à comarca da Maia no ano de 1748, levou consigo um meirinho, um secretário e 12 a 14 cozinheiros e copeiros. O séquito fazia-se transportar por 18 bestas e um cavalo de estado. Já o arcebispo de Braga era acompanhado por 40 pessoas e 60 bestas $^{14}$.

Na prática os prelados, na maioria das vezes, delegavam o poder em visitadores, recrutados de entre as elites eclesiásticas da diocese, como provisores ou vigários gerais. A comitiva nestes casos era bastante reduzida, quando comparada com a das visitas levadas a cabo pelo prelado em pessoa. Para cada visitação eram assim nomeados um visitador e um secretário,

${ }^{13}$ Biblioteca Nacional de Portugal (Lisboa), Reservados, Pombalina, n. ${ }^{\circ} 498$, tomo I, fls. não numerados (doravante BNP, RP 498 I). Sobre as comitivas das visitas pastorais no arcebispado de Braga e a sua regulamentação desde o IV Concílio Provincial (1566-1567) até ao Regimento de 1699, cf. SOARES, António Franquelim Sampaio Neiva - A Arquidiocese de Braga..., cit., p. 218-229.

${ }^{14}$ BNP, RP 498 I. António Franquelim Sampaio Neiva Soares deu a conhecer as comitivas de outros prelados bracarenses. D. Frei Bartolomeu Fernandes dos Mártires levava consigo cerca de 20 pessoas. Mais tarde, na segunda metade de seiscentos, D. Veríssimo de Lencastre integrava uma comitiva de 23 indivíduos, cf. SOARES, António Franquelim Sampaio Neiva - A Arquidiocese..., cit., p. 237-238. 
que se faziam acompanhar por dois ou três criados, um almocreve e um pajem ou porteiro da visitação ${ }^{15}$.

2. Na sessão XXIV, cânon 3, De reformatione, do Concílio de Trento (1545-1563), a pratica da visita pastoral foi pormenorizadamente abordada. No que respeita ao agasalho dos prelados o Concílio acordou que estes "satisfeitos com huma modesta equipagem, procurem concluir a visita o mais breve que poder ser, ainda que com a devida diligencia"16. Proibiu os bispos de aceitar dádivas no decorrer da visita, "exceptuando porém vitualhas, que a elle, e aos seus se ministrarão com parcimonia, e moderação, somente quando o pedir a necessidade dos tempos, e não mais. Naquelles lugares porém, ou Províncias, onde he costume não se receberem vitualhas, nem dinheiro, nem outra alguma cousa, mas fazer-se tudo de graça, se continue em observar isto mesmo" 17 . Os bispos deviam de resto guardar modéstia nas alfaias e na mesa, servindo de exemplo aos fiéis ${ }^{18}$.

Em Portugal foram vários os textos produzidos com o intuito de regulamentar as visitações ${ }^{19}$. Nas constituições diocesanas as referências à visita pastoral são constantes. As Constituições Sinodais do Bispado de Coimbra de 1591, não obstante serem as mais detalhadas no que respeita às visitas pastorais ${ }^{20}$, não possuem nenhuma constituição específica sobre o agasalho dos visitadores. Simplesmente é referido que estes "não pousarão em as casas dos Priores, Reytores, ou Curas onde visitarem, achando em o lugar outras pousadas convenientes, nem lhes peção, ou aceytem delles jantares, ceas, ou presentes ou mantimentos: salvo sendo cousa tão pequenas que o direyto as não defende" ${ }^{21}$. Já as constituições do bispado do Porto

\footnotetext{
${ }^{15}$ Sobre o pessoal das visitações cf. SOARES, António Franquelim Sampaio Neiva A Arquidiocese..., cit., p. 231-242.

${ }^{16}$ REYCEND, João Baptista - O Sacrosanto, e Ecuménico Concilio de Trento em Latim e em Portuguez, tomo II. Lisboa: Oficina Patriarcal, 1781, p. 271.

${ }^{17}$ REYCEND, João Baptista - O Sacrosanto..., cit., p. 273.

${ }^{18}$ REYCEND, João Baptista - O Sacrosanto..., cit., p. 409-413.

19 PAIVA, José Pedro - Uma instrução..., cit., p. 637-654.

${ }^{20}$ BETHENCOURT, Francisco - As visitas pastorais..., cit., p. 98; PAIVA, José Pedro Uma Instrução..., cit., p. 640-641; CARVALHO, Joaquim Ramos de, PAIVA, José Pedro Visitações..., cit., p. 367.

${ }^{21}$ Constituições Sinodais do Bispado de Coimbra..., cit., fl. 182v. A propósito do local onde os prelados ficavam alojados conhecemos alguns dados referentes ao bispo de Leiria
} 
e as do arcebispado de Braga dedicaram uma constituição ao assunto ${ }^{22}$. Os visitadores deviam ser moderados nos gastos, controlando igualmente os da sua comitiva, a qual devia quanto possível ser limitada. Estavam proibidos de cobrarem mais que uma procuração diária, bem como de aceitarem outras refeições ou dádivas por parte dos visitandos ${ }^{23}$. Advertia-se para que não ficassem alojados nas casas dos religiosos que houvessem de visitar, evitando dessa forma pressões "[...] para que mais livremente possão fazer seu officio" 24 . No caso de não se acharem presentes aqueles que estavam obrigados a dar o agasalho, o recebedor das penas tomaria nota das despesas, ficando sequestrada parte da renda da igreja visitada, para obrigar a pagar os gastos. O que terá motivado a inclusão de um ponto específico dedicado à procuração dos visitadores naquelas duas constituições sinodais? Por ventura a existência de um número elevado de conflitos causados pelo pagamento da procuração? De facto, a sua liquidação não se fez sem a existência de desaguisados. Não esqueçamos as queixas denunciando os abusos dos visitadores no exercício da visita pastoral ${ }^{25}$. Por exemplo, em 1748, no bispado do Porto, comarca da Maia, o rendeiro da comenda de Lordelo de Ouro recusou-se a pagar a procuração pelo que foi preso e condenado em 12 mil réis. Na sequência deste episódio o rendeiro enviou à Mesa da Consciência e Ordens um memorial anónimo, suposto que em nome de todos os rendeiros das comendas da Ordem de Cristo daquela comarca,

D. João de Nossa Senhora da Porta. Na visita que fez a Ourém em Julho de 1747, ficou alojado na quinta da Caridade. Mais tarde, em Setembro de 1748, na visitação que realizou a Porto de Mós ficou instalado numa quinta perto da vila, propriedade de João Barreiros, cavaleiro da Ordem de Cristo, cf. OLIVEIRA, Ricardo Pessa de - Uma vida no Santo Ofício: o Inquisidor Geral D. João Cosme da Cunha. Lisboa: Dissertação de Mestrado em História Moderna apresentada à Faculdade de Letras da Universidade de Lisboa, 2007, exemplar mimeografado, p. 37-41.

${ }^{22}$ Constituições Synodais do Bispado do Porto. Porto: José Ferreira, 1690, p. 662-663; Constituiçoens Synodaes do Arcebispado de Braga. Lisboa: Oficina de Miguel Deslandes, 1697, p. 497-498.

${ }^{23}$ Constituições Synodais do Bispado do Porto..., cit., p. 663. No regimento do Auditório Eclesiástico do mesmo bispado no título XII, intitulado Dos visitadores, \& o que a seu officio pertence, também se fazia saber aos visitadores que "[...] não comão, nem bebão com clerigos, nem leigos, nem os convidem para isso [...]", cf. Regimento do Auditório Ecclesiastico do Bispado do Porto, e dos Officiais da Justiça Ecclesiastica do mesmo Bispado. Porto: José Ferreira, 1690, p. 93.

${ }^{24}$ Constituiçoens Synodaes do Arcebispado de Braga..., cit., p. 498.

${ }^{25}$ CARVALHO, Joaquim Ramos de, PAIVA, José Pedro - Visitações..., cit., p. 366. 
com listas falsas e alteradas relatando os supostos abusos do prelado. Perante a denúncia a Mesa da Consciência mandou informar judicialmente dos procedimentos do bispo ${ }^{26}$.

Mas o descontentamento relativo à procuração não se manifestava apenas por parte dos que estavam obrigados ao seu pagamento. Tal é perceptível nas constituições do bispado da Guarda, as quais referiam que "quanto aos jantares, colheitas, ou procurações que se Nos devem, \& aos nossos Visitadores, pagarsehão como tégora se costumou: \& sem embargo que era cousa justa acrescentarem-se algũas colheitas por serem mui piquenas, $\&$ desiguaes ao mantimento que se devia aos Visitadores (em lugar do qual forão ordenadas) com tudo por fazermos graça, \& favor à Cleresia de nosso Bispado, não alteramos por hora cousa algũa"27.

Além das Constituições também os regimentos dos oficiais de justiça e do auditório eclesiástico regulavam a prática da visita pastoral e as funções dos visitadores ${ }^{28}$. A propósito da matéria que nos ocupa veja-se o regimento do bispado de Viseu, no qual se proíbe o visitador de receber presentes e se adverte que "somente acceitarão dos Abbades, \& mais parochos a procuração ordinaria, ou agazalho de suas pessoas e officiaes que segundo Direito, \& Sagrado Concilio Tridentino se lhes deu. E se destes teverem ainda algũa enformação sospeitosa, não pousaram em suas casas achando outras, em que se possam agasalhar" 29 . O mesmo texto referia que os rendeiros que faltassem com o agasalho aos visitadores seriam condenados em 500 réis para a Sé e meirinho, enquanto os curas que fugissem a semelhante obrigação seriam condenados em 200 réis. Os visitadores deviam levar consigo o rol das colheitas das igrejas daquela diocese "pera as arrecadarem quando os Abbades, ou comendadores lhes nam derem a comida, \& gasalho conveniente [...] e o escrivam fará hum caderno, em que as va assentando assi como

${ }^{26}$ BNP, RP 498 I. Cf. igualmente, SOARES, António Franquelim Sampaio Neiva A Arquidiocese ..., cit., p. 341-342.

${ }^{27}$ Constituições Synodais do Bispado da Goarda. Lisboa: Miguel Deslandes, 1686, p. 588.

${ }^{28}$ Excepção feita aos regimentos de Coimbra, Leiria e Elvas que não se referem à figura do visitador, cf. PAIVA, José Pedro - Uma instrução..., cit., p. 645.

${ }^{29}$ Regimento do Auditorio Ecclesiastico do Bispado de Viseu, e dos Officiaes da Justiça Ecclesiastica do dito Bispado. Coimbra: Nicolau Carvalho, 1617, p. 62. 
as for arrecadando o visitador, carregando-as sobre elle, $\&$ fazendo disso termos, que assinará o dito visitador"30.

Outros textos serviram o propósito de regulamentar a mesma prática, de entre estes destaque para as várias instruções manuscritas, tal como a Instrução para os visitadores do bispado de Coimbra redigida provavelmente no último quartel do século XVII, e os tratados impressos de Mateus Soares e de Lucas de Andrade. O autor da Practica e Ordem Pera os Visitadores dos Bispados [...] dedicou um capítulo à questão da procuração concedida ao visitador. Segundo Mateus Soares "a causa porque parece que se entroduzio esta procuração ou gentar aos ditos prelados \& seus visitadores foy pera que com mais diligencia, \& cuidado se despertasem, \& inuitassem a comprir com sua obrigação da visitação, \& não areceassem em algũs lugares esteriles e de montanha alongados das cidades ou villas as faltas dos mantimentos, $\&$ aquillo que elles deuião de gastar em levarem, \& buscarem os ditos mantimentos o gastem com pobres ou em outras necessidades comuns, $\&$ assi ja que elles vão semear doutrina spiritual quis a lei canonica que os provessem com algũa comoda sustentação corporal”31 . No mesmo capítulo o autor indicou o modo como as igrejas pobres haveriam de pagar a procuração, deu conta da existência de colheitas taxadas por composições antigas, de como proceder com o agasalho e procuração em casos específicos, tal como em visitações levadas a cabo pelo cabido às "igrejas que per posse, \& custume se custumam visitar pello dito cabbido", chamando ainda a atenção para que houvesse por parte dos visitadores moderação e que estes fossem acompanhados por séquito reduzido ${ }^{32}$.

Lucas de Andrade não dedicando um capítulo ao agasalho do prelado forneceu ao longo do tratado algumas indicações a este respeito, indicando qual o melhor período do ano para se proceder à visita, a quem cabia a preparação do agasalho do bispo, qual a dimensão que deveria ter a sua comitiva e apontando algumas das pessoas que deveriam acompanhar o

${ }^{30}$ Regimento do Auditorio Ecclesiastico do Bispado de Viseu..., cit., p. 68.

${ }^{31}$ SOARES, Mateus - Practica e Ordem Pera os Visitadores dos Bispados, na qual se decidem muitas questiões, assi em causas civis, como criminais, pertencentes aos Avogados, no foro ecclesiastico, \& secular, com intendimento de algũas Extravagantes dos Summos Pontífices, \& concordatas deste Reino de Portugal. Lisboa: Jorge Rodrigues, 1602, fls. 26v-27.

${ }^{32}$ SOARES, Mateus - Practica e Ordem..., cit., fls. 27-29v. 
bispo. Segundo o autor o pároco devia preparar "o agazalho do Prelado, \& concerto da caza donde se houver de hospedar, \& assim a família que levar consigo, que serão até dez pessoas, \& seis ou sete cavalgaduras, \& o necessario pera ellas [...]"33. Por seu turno as comitivas que acompanhavam os visitadores enviados pelo bispo não deviam exceder as seis pessoas ${ }^{34}$.

Um memorial do século XVIII mencionava que, de acordo com um decreto de Clemente XI (1700-1721), os visitadores ordinários podiam levar de comitiva um máximo de seis pessoas e sete bestas. Por seu turno, os prelados poderiam ser acompanhados, no máximo, por 12 pessoas e outras tantas cavalgaduras, além das da sua liteira. O mesmo documento referia que "[...] he mais que claro, e tambem constante em Direito se devão nas vezitas as procuraçoens, ou sejão os gastos que nella se fazem, fazendoos prontos em propria especie ou em dinheiro como premite o Concilio, mas tão somente do que he percizo e necessario ao vezitador e à sua cometiva nos dias que se detiver na vezita, e ainda aos alugueis das cavalgaduras para os menistros, e officiais necessarios ao bispo [... $]^{\prime 35}$.

3. O estudo dos tributos, também designados por colheitas, que os bispos recebiam no momento em que visitavam as igrejas dos seus bispados pode ser interessante para o conhecimento da alimentação deste grupo.

Ao entrar no campo da história da alimentação é necessário ter em consideração determinadas variáveis tais como o poder de compra, a localização geográfica, a época do ano, o tipo de refeição, isto é, refeição ordinária ou banquete, a abundância e o preço dos alimentos. A nutrição do povo diferenciava da dos grupos sociais privilegiados não só em quantidade e em qualidade, mas também na forma de confecção dos alimentos ${ }^{36}$.

Na Idade Média os cereais e o vinho constituíam a base da alimentação do povo, o qual utilizava igualmente com alguma frequência hortaliças e legumes. Da dieta alimentar constaria também alguma carne, peixe e fruta.

${ }^{33}$ ANDRADE, Lucas de - Visita Geral..., cit., p. 37.

${ }^{34}$ ANDRADE, Lucas de - Visita Geral..., cit., p. 228.

${ }^{35}$ BNP, RP 498 I.

${ }^{36}$ BRAGA, Isabel M. R. Mendes Drumond - Alimentação, Etiqueta e Sociabilidade em Portugal no século XVIII in Cultura, Religião e Quotidiano. Portugal (século XVIII). Lisboa: Hugin, 2005, p. 168. 
Era um regime alimentar em que a quantidade se sobrepunha à qualidade, altamente calórico e deficitário de vitaminas e sais minerais.

A carne, assada, cozida, picada ou estufada, constituía a base da alimentação dos privilegiados. Eram consumidas carnes de matadouro, tais como vaca, porco, carneiro e cabrito, mas também espécies de caça e aves de criação. A actividade venatória proporcionava às mesas gamos, zebros, cervos, corços, lebres e uma grande variedade de aves, tais como perdizes e patos bravos. Entre as aves de criação contavam-se galinhas, patos e pombos. O peru apenas entraria na mesa dos europeus após a chegada destes à América ${ }^{37}$.

O consumo de peixe esteve intimamente ligado às prescrições religiosas, sendo gasto sobretudo nos dias magros. Entre as espécies mais consumidas encontrava-se a pescada, a sardinha, o congro, o sável, o salmonete e a lampreia. Com alguma frequência eram degustados crustáceos. O peixe era consumido fresco, mas também seco, salgado e fumado ${ }^{38}$. São de referir o largo emprego de ovos, o consumo de leite ${ }^{39}$, sobretudo através dos seus derivados, e a utilização de diversos temperos, tais como alho, sumo de agraço e vinagre, a par de especiarias de que é exemplo a pimenta ${ }^{40}$.

37 Sobre o peru e outros alimentos provenientes do continente americano cf. BRAGA, Isabel M. R. Mendes Drumond Braga - A Herança das Américas em Portugal. Trópico das Cores e dos Sabores. Lisboa: CTT Correios de Portugal, 2007, p. 78-221.

${ }^{38}$ A propósito do consumo de peixe cf. SANTOS, Maria José Azevedo - O Peixe e a Fruta na Alimentação da Corte de D. Afonso V. Breves Notas. Brigantia. vol. III, 3 (1983) p. 307-343; BRAGA, Isabel M. R. Mendes Drumond - O Peixe na Dieta Alimentar dos Portugueses in Do Primeiro Almoço à Ceia. Estudos de História da Alimentação. Sintra: Colares Editora, 2004, p. 35-59.

${ }^{39}$ A respeito deste género alimentar cf. BRAGA, Paulo Drumond - Leite. Biografia de um Género Alimentar. Sintra: Colares Editora, 2004.

${ }^{40}$ Sobre a alimentação medieval cf. de entre outros MARQUES, A. H. de Oliveira A Sociedade Medieval Portuguesa. Aspectos de vida Quotidiana. 4. ${ }^{\text {a }}$ edição. Lisboa: Sá da Costa, 1981, p. 7-22; Idem -A Vida Quotidiana in SERRÃO, Joel and MARQUES, A. H. de Oliveira (ed.) - Nova História de Portugal. IV. Lisboa: Editorial Presença, 1987, p. 464-466; GONÇALVES, Iria - Acerca da Alimentação Medieval. Revista da Faculdade de Letras de Lisboa. IV série, 2 (1978) 441-458; Idem - A Colheita Régia Medieval, Padrão Alimentar de Qualidade (Um Contributo Beirão). Revista da Faculdade de Ciências Sociais e Humanas. 6 (1992-1993) 175-189; Idem - Alimentação Medieval: Conceitos, Recursos, Práticas. Actas dos VI Cursos Internacionais de Verão de Cascais. vol. II. Cascais: Câmara Municipal de Cascais, 2000, p. 29-48; Idem - Entre a Abundância e a Miséria: As Práticas Alimentares da Idade Média Portuguesa in ANDRADE, Amélia Aguiar and SILVA, José Custódio Vieira da - Estudos Medievais. Quotidiano Medieval: Imaginário, Representação e Práticas. Lisboa: 
Entre as gorduras utilizadas para a confecção dos repastos contavam-se a banha de porco, o toucinho, a manteiga e o azeite ${ }^{41}$.

O século XVIII não apresentou mudanças significativas no que respeita à alimentação. As transformações passaram sobretudo pela divulgação crescente de produtos de luxo como o chá, café e chocolate e por um maior consumo de lacticínios, ao mesmo tempo que se registou um maior consumo de vegetais e frutas ${ }^{42}$. Não se verificaram mudanças nas espécies de carnes consumidas, ao contrário do peixe cuja variedade aumentou. Existiu um acréscimo no número de condimentos e especiarias utilizados na confecção das refeições. Relativamente às gorduras utilizadas o azeite perdeu o relevo que detinha, passando a ser utilizado sobretudo na preparação de pratos de peixe. Em contrapartida o toucinho passou a ser a gordura de excelência na confecção de carnes ${ }^{43}$. De referir ainda o aumento no consumo e na qualidade do vinho ${ }^{44}$.

No que respeita às refeições diárias, existiam duas principais: o jantar e a ceia. Estas eram por vezes as únicas, não obstante existirem informações de almoços e merendas ${ }^{45}$. De entre todas as refeições a mais importante era

Livros Horizonte, 2004, p. 43-67; Idem - A Propósito do pão da cidade na Baixa Idade Média in SILVA, Carlos Guardado da (ed.) - História da Alimentação, Turres Veteras IX. Lisboa: Edições Colibri, Torres Vedras, Câmara Municipal de Torres Vedras, Instituto de Estudos Regionais e do Municipalismo Alexandre Herculano, 2007, p. 49-72; COELHO, Maria Helena da Cruz - Apontamentos sobre a Comida e a Bebida do Campesinato Coimbrão em tempos Medievos in Homens, Espaços e Poderes. Séculos XI-XVI, vol. I, Notas do Viver Social. Lisboa: Livros Horizonte, 1990, p. 9-22; RODRIGUES, Carla Devesa - Do pão e do vinho: Esboços de dois víveres no Portugal da Baixa Idade Média in SILVA, Carlos Guardado da (ed.) - História da Alimentação..., cit., p. 73-84.

${ }^{41}$ FERRO, João Pedro - Arqueologia dos Hábitos Alimentares, introdução de A. H. de Oliveira Marques. Lisboa; Dom Quixote, 1996, p. 31.

${ }^{42}$ FERRO, João Pedro - Arqueologia ..., cit., p. 15; BRAGA, Isabel M. R. Mendes Drumond - Alimentação, Etiqueta..., cit., p. 169.

${ }^{43}$ MARQUES, A. H. de Oliveira, FERRO, João Pedro - L'Alimentation au Portugal du Moyen Age au XVIII Siècle", La Sociabilité à table. Commensalité et Convivialité à travers les ages in Actes du Colloque de Rouen. Rouen: Publications de l'Université de Rouen, 1992, p. 286; FERRO, João Pedro - Arqueologia ..., cit., p. 25-27 e 31.

${ }^{44}$ MARQUES; A. H. de Oliveira, FERRO, João Pedro - L'Alimentation..., cit., p. 287.

${ }^{45}$ No século XVI, o pequeno-almoço dos estudantes da Universidade de Coimbra era composto unicamente por pão, cf. OLIVEIRA, João Carlos - A Alimentação in SERRÃO, Joel e MARQUES, A. H. de Oliveira (ed.) - Nova História de Portugal. V, Do Renascimento à Crise Dinástica, coordenação de João José Alves Dias. Lisboa: Editorial Presença, 1998, p. 624. Sobre a alimentação dos estudantes da Universidade de Coimbra cf. OLIVEIRA, 
o jantar que, a partir de finais do século XIV, tinha lugar entre as 10 e as 11 horas $^{46}$. Entre os mais abastados era constituído por três pratos, não entrando neste número sopas, acompanhamentos e sobremesas. A ceia, repasto geralmente mais leve, desenrolava-se ao final da tarde, sendo constituída, em média, por dois pratos.

\section{Um manuscrito não datado permite conhecer as colheitas taxadas} que o bispo de Coimbra recebia cada ano que visitava as igrejas do seu bispado $^{47}$. Entre estas contavam-se as das igrejas de Abiúl, Louriçal,

António - O Quotidiano da Academia in História da Universidade em Portugal. vol. I, tomo II, (1537-1771). Coimbra: Universidade de Coimbra, Fundação Calouste Gulbenkian, 1997, p. 637-642. Mais tarde, já no século XVIII, no Colégio dos Nobres de Lisboa o almoço, tomado entre as 07:15 horas e as 08:00 horas dependendo do período do ano, era constituído por biscoitos, pão torrado com manteiga e café/chá com leite. Às sextas-feiras bebia-se leite com chocolate e comia-se pão-de-ló. A merenda tomada ao final da tarde era composta por torradas, fruta ou queijo, conforme a época do ano cf. CRESPO, Jorge, HASSE, Manuela AAlimentação no Colégio dos Nobres de Lisboa (1766-1831). Revista de História Económica $e$ Social. 7 (1981) 96-97.

${ }^{46} \mathrm{O}$ jantar foi sendo progressivamente atrasado, tendo como consequência a instituição de um almoço, cf. MARQUES; A. H. de Oliveira, FERRO, João Pedro - L'Alimentation..., cit., p. 284; FERRO, João Pedro - Arqueologia..., cit., p. 19.

${ }^{47}$ Instituto Arquivos Nacionais/Torre do Tombo, (Lisboa), Mesa da Consciência e Ordens (M.C.O.), Ordem de Cristo (O.C.), Convento de Tomar (C.T.), livro 264 [Colheitas que o bispo de Coimbra ha d'aver em cada hum anno]. No inventário realizado por FARINHA, Maria do Carmo Jasmins Dias, JARA, Anabela Azevedo - Mesa da Consciência e Ordens. Lisboa: Instituto dos Arquivos Nacionais/Torre do Tombo, Direcção de Serviços de Arquivística, 1997, p. 285, é sugerido que o manuscrito data do século XIII. No entanto, no próprio livro é indicado a lápis como sendo do século XIV. Além disso, existe referência às igrejas da Ordem de Cristo pelo que terá de ser posterior a 1319. Segundo António Franquelim Sampaio Neiva Soares a colheita não se identificava com a procuração, uma vez que era paga todos os anos, inclusive naqueles em que não ocorresse visita pastoral. A colheita consistiria, na maior parte das vezes, em uma módica quantia em dinheiro, cf. SOARES, António Franquelim Sampaio Neiva - A Arquidiocese..., cit., p. 291-292. De facto, o título do livro 264 [Colheitas que o bispo de Coimbra ha d'aver em cada hum anno] sugere isso mesmo, ou seja um tributo pago anualmente, desligado da procuração. Não obstante, num outro documento surge mencionado que "as sobreditas igrejas matriz [São Martinho da vila de Pombal] e annexas que so hião a ser ermidas e hora são curadas e feytas freguezias são vizitadas pelo Bispo de Coimbra em pessoa [...] pela qual vizitação há hum jantar chamado colheyta á custa da renda da commenda e não vindo em pessoa não vence couza alguma e de que consta o jantar em colheyta he o seguinte [...]", cf. Instituto Arquivos Nacionais/ /Torre do Tombo, (Lisboa), M.C.O., Tombo das Comendas, livro, 409, fls. 79-79v. Portanto, parece que neste caso a colheita estava ligada ao gasalho do prelado, só sendo paga nos anos em que a igreja fosse visitada pessoalmente pelo prelado. 
Pombal e Redinha ${ }^{48}$. Analisando a colheita de Pombal parece que esta se fixou relativamente cedo, mantendo-se inalterada ao longo dos séculos ${ }^{49}$. Tanto no manuscrito aludido, como no tombo dos bens pertencestes à comenda de Pombal, de Março de 1508, como no tombo da comenda de São Martinho da vila de Pombal de Novembro de 1733, o tributo registado é exactamente o mesmo ${ }^{50}$. Este consistia num jantar, pago à custa da renda da comenda, que só venceria caso a visita fosse levada a cabo pelo prelado em pessoa até ao dia de São João Batista, ou seja 24 de Junho ${ }^{51}$. Sendo a visita na esmagadora maioria das ocasiões levada a cabo por visitadores

${ }^{48} \mathrm{O}$ interesse nestas quatro freguesias prende-se com o facto de corresponderem a parte do território que estamos a estudar na nossa tese de doutoramento, intitulada provisoriamente Confessionalização e Disciplinamento Social: Pombal (1563-1820). As colheitas de Abiúl, Pombal e Redinha são praticamente iguais, registando-se a única diferença no número de carneiros. Em Pombal eram tributados seis carneiros, enquanto em Abiúl e na Redinha esse número descia para quatro. Outro sim a colheita de Abiúl não compreendia varas de bragal para os cozinheiros. Já a colheita do Louriçal era significativamente mais reduzida o que resultaria de menores possibilidades económicas.

${ }^{49}$ Esta realidade não seria exclusiva de Pombal. O regimento do auditório eclesiástico do Algarve também transparece esta ideia de continuidade: "no que toca ao gazalhado de sua pessoa [visitador], \& Officiaes se guardará o costume que universalmente achamos se guarda, \& pratica em todo este nosso Bispado de tempo immemorial a esta parte", cf. Regimento do Auditorio Ecclesiastico do Bispado do Algarve. Évora: Imprensa da Universidade, 1674, p. 10 .

${ }^{50}$ Instituto Arquivos Nacionais/Torre do Tombo, (Lisboa), M.C.O., O.C., C.T., livro, 308, fl. 65-65v, publicado em Tombos da Ordem de Cristo. III, Comendas do Vale do Mondego (1508). Lisboa: Centro de Estudos Históricos, Universidade Nova de Lisboa, 2006, p. 275-276; Instituto Arquivos Nacionais/Torre do Tombo, (Lisboa), M.C.O., Tombo das Comendas, livro, 409, fls. 79-79v.

${ }^{51}$ A visitação devia ser realizada "no tempo da Primavera, desde a Paschoa atè Setembro, $\&$ Outubro, porque este nosso Portugal he tempo em que se não padece o detrimento dos maos caminhos, as molestias dos rios, a falta das coisas necessarias pera se acomodarem as pessoas, que acompanhão os Prelados, os descomodos das vivendas dos Parochos, em muitas partes, os mantimentos que se podem conduzir com a comodidade que se requere [...]", cf. ANDRADE, Lucas de - Visita Geral..., cit., p. 8-9. Antes de se proceder à visita era enviado um edital e uma carta do bispo ao pároco da igreja a visitar de forma que "tenhão tempo os Parochos pera prevenir o necessario, assim pera o acto da visita, como pera agazalhar o Arcebispo, \& a gente que for em sua companhia, como são obrigados \& o dispoem o Concilio Tridentino", cf. ANDRADE, Lucas de - Visita Geral..., cit., p. 24. Nos Açores verificou-se um suporte financeiro da Coroa à visita pastoral. Por exemplo, no ano de 1585, Filipe I permitia que a Fazenda Real suportasse as despesas com as viagens, mas também o sustento da comitiva, com a pousada, alimentação e cavalgaduras, cf. ENES, Maria Fernanda - Reforma Tridentina..., cit., p. 32; COSTA, Susana Goulart - Viver e Morrer..., cit., p. 62. 
nomeados pelo prelado é caso para perguntar o que sucederia nesses anos? Não seria fornecida qualquer sustentação? Ou pelo contrário seria enviado um rol pelo visitador solicitando o necessário? Outra questão prende-se com a data apontada como limite para o pagamento da procuração. No que toca à primeira metade do século XVIII, tendo em conta a documentação conservada, apenas por duas vezes a vila foi visitada pelo prelado. Na primeira ocasião, a 1 de Agosto de 1712, por D. António de Vasconcelos e Sousa, na segunda a 23 de Julho de 1745, por D. Miguel da Anunciação ${ }^{52}$. Em ambos os casos a visita ocorreu em data posterior ao dia de São João Batista. O que sucederia nestas situações? Terá motivado resistências ao pagamento da procuração? São perguntas para as quais não encontrámos até ao momento resposta.

A colheita recebida pelo prelado em Abiúl, Pombal e Redinha compreendia cereais, vinho, carnes, gorduras para a confecção dos repastos, adubos, isto é, temperos, adoçantes e ovos. Além destes eram devidos tecidos: duas varas de bragal para os cozinheiros, sendo que cada vara correspondia a 1,10 metros, e um afusal de linho, equivalente a dois arráteis, ou seja 0,680 quilos ${ }^{53}$. O tributo compreendia igualmente uma libra de cera, isto é 0,489 quilos a 0,326 quilos, três cargas de lenha, duas de palha e dinheiro: quarenta soldos para os escudeiros e cinco para o mordomo ${ }^{54}$.

${ }^{52}$ Arquivo da Universidade de Coimbra (Coimbra), Penela, Devassas, livro 54, fl. 2 e livro 62, fl. 115.

${ }^{53}$ Para os pesos e medidas utilizámos os textos de MARQUES, A. H. de Oliveira - Pesos e Medidas in SERRÃO, Joel (ed.) - Dicionário de História de Portugal. V. Porto: Livraria Figueirinhas, 1981, p. 67-72; e BRAGA, Isabel M. R. Mendes Drumond - A Circulação e a Distribuição dos Produtos in SERRÃO, Joel and MARQUES, A.H. de Oliveira - Nova História ..., cit., p. 207-208. A propósito do bragal Rafael Bluteau referiu que as gentes rústicas o utilizavam para fazer toalhas de mesa e guardanapos, acrescentando que as amassadeiras tinham o costume de o usar para cobrir "no taboleiro por baixo, \& por cima, a maça feita em pão”, cf. BLUTEAU, Rafael - Vocabulario Portuguez e Latino. tomo II. Coimbra: Colégio das Artes da Companhia de Jesus, 1712, p. 178. Parece-nos que neste caso a segunda hipótese se afigura mais plausível. Quanto à finalidade do linho talvez servisse para cozer os sapatos dos homens de pé da comitiva. No arcebispado de Braga o regimento de 1699 previa que fossem dados aos homens de pé sapatos novos e os concertos necessários durante a visitação, que na prática se traduziam em solas e outras despesas do género, cf. SOARES, António Franquelim Sampaio Neiva - A Arquidiocese..., cit., p. 226 e 237.

${ }^{54} \mathrm{Da}$ colheita paga no Louriçal estavam ausentes adoçantes e dinheiro. 
O pão presente em todas as mesas variava na qualidade conforme o poder económico do agregado familiar. Os grupos privilegiados consumiam pão de trigo, alvo, produzido com farinha peneirada diversas vezes, de forma a retirar todos os farelos e sêmeas ${ }^{55}$. Na colheita de Abiúl, Pombal e Redinha estava incluída uma teiga, isto é, cerca de 30 quilos, de farinha branca, bem peneirada para a mesa do prelado ${ }^{56}$. Estavam ainda compreendidos seis quarteiros de farinha peneirada "polla pineira de ante mãao", igual quantia de cevada, sendo que cada quarteiro equivalia a $1 / 4$ de moio, ou seja 200 quilos, um alqueire de milho para a lavadeira e igual quantidade para os cães. No Louriçal apenas eram devidos dois quarteiros de farinha peneirada e idêntica quantidade de cevada, bem como um alqueire de milho para a lavadeira. A cevada registada seria para a alimentação das bestas em que a comitiva se fazia transportar.

Tal como o pão, o vinho entrava na dieta alimentar de toda a população, podendo ser consumido cru, mas também cozido. Como ideal de frugalidade devia ser misturado com água ${ }^{57}$. Em Pombal, como nas vilas de Abiúl e da Redinha, a quantidade de vinho foi estipulada em seis puçais, isto é 30 almudes, equivalentes a 540 litros. No Louriçal a porção de vinho devida em colheita descia para os 12 almudes, correspondentes a $216 \operatorname{litros}^{58}$.

No que respeita à carne, a colheita compreendia carnes de matadouro e aves de capoeira. Entre os primeiros contavam-se seis carneiros, quatro cabritos, dois leitões e uma vaca ou um porco, dependendo do período do ano. Entre as aves eram devidas 12 galinhas, quatro capões e dois patos ${ }^{59}$.

${ }^{55}$ GONÇALVES, Iria - Entre a Abundância..., cit., p. 48-49.

${ }^{56}$ A teiga não tinha medida certa, mas com frequência era calculada em dois alqueires, cf. MARQUES, A. H. de Oliveira - Pesos..., cit., p. 71.

${ }^{57}$ MARQUES, A. H. de Oliveira - A Sociedade Medieval..., cit., p. 16; OLIVEIRA, João Carlos - A Alimentação..., cit., p. 620-621. COELHO, Maria Helena da Cruz Apontamentos..., cit., p. 10-11.

${ }^{58}$ MARQUES, A. H. de Oliveira - Pesos..., cit., p. 70. BRAGA, Isabel M. R. Mendes Drumond - A Circulação..., cit., p. 208 mencionou que um almude equivalia a 16,95 litros. Desta forma em Abiúl, Pombal e Redinha seriam devidos cerca de 508,5 litros e no Louriçal 203,4 litros.

${ }^{59}$ No que respeita à carne, a colheita do Louriçal apenas compreendia quatro carneiros, um porco de 30 soldos, meia vaca e 12 galinhas, cf. Instituto Arquivos Nacionais/Torre do Tombo, (Lisboa), M.C.O., O.C., C.T., livro 264, fls. não numerados. 
Nas quatro localidades, para o tempero das vitualhas estavam incluídos um almude de vinagre, um alqueire de sal, uma réstia de alhos e outra de cebolas. Como gordura apenas surgia a manteiga, no caso de Abiúl, Pombal e Redinha um alqueire, isto é 18 a 14 quilogramas, dependendo da região, e no Louriçal uma quarta, ou seja de 4,5 a 3,5 quilos. De notar a ausência do azeite, tanto mais que esta era uma das principais culturas da região, sobretudo em Abiúl ${ }^{60}$. Entre as especiarias apenas uma onça de açafrão e uma libra de pimenta de 27 onças, sendo que a onça equivalia a 0,030 quilogramas. No Louriçal o tributo incluía cinco soldos para adubos ${ }^{61}$.

Já aqui destacámos o largo consumo de ovos, intimamente ligado com a abundância de criação. De facto, estes integravam praticamente todas as receitas elaboradas, podendo ser comidos cozidos, escalfados, mexidos, fritos ou recheados. Não esqueçamos o uso que deles fez a doçaria portuguesa, desenvolvida sobretudo nos séculos XVII e XVIII ${ }^{62}$. De tal forma não espanta a presença de número elevado de ovos na colheita em análise: 60 em Abiúl, Pombal e Redinha, 24 no Louriçal. A propósito da doçaria é de mencionar a inclusão de mel no tributo, a saber um alqueire. A doçaria medieval, pouco desenvolvida, substituía não poucas vezes o açúcar, de preço elevado, pelo mel. Na confecção de pratos principais o mel também poderia entrar, sendo usual misturar o doce com o salgado. Mais tarde, a partir do século XVI, o uso do açúcar generalizou-se sendo largamente utilizado pela confeitaria ${ }^{63}$.

Comparemos as procurações do bispado de Coimbra estudadas com as do bispado da Guarda. Na igreja de Santa Maria da vila de Castelo Branco a procuração consistia em 225 alqueires de trigo, outros tantos de centeio e 120 almudes de vinho. Anos havia em que o cereal e o vinho eram pagos em

${ }^{60}$ OLIVEIRA, Ricardo Pessa de, GOMES, Saul António - Notícias e Memórias Paroquiais Setecentistas, 9, Pombal. Coimbra, Pombal: Centro de História da Sociedade e da Cultura, Palimage Editores, [no prelo].

${ }^{61} \mathrm{O}$ pagamento das especiarias não poucas vezes era feito em moeda, podendo depois ser adquiridas por algum oficial da ucharia que acompanhasse o prelado, ou por alguém que no decorrer da visita tivesse funções idênticas. O mesmo acontecia com a colheita régia medieval, cf. GONÇALVES, Iria - A Colheita Régia..., cit., p. 183.

${ }^{62}$ MARQUES, A. H. de Oliveira - A Sociedade Medieval..., cit., p. 14; FERRO, João Pedro - Arqueologia ..., cit., p. 32.

${ }^{63}$ GONÇALVES, Iria - A Colheita..., cit., p. 184-185. 
espécie, enquanto em outros era pago em dinheiro. $\mathrm{O}$ tributo compreendia ainda 40 galinhas, seis carneiros, dois porcos e duas vacas. Como em todas as procurações o número de ovos era avultado, neste caso chegava às duas centenas. Para temperar e condimentar as refeições eram devidas duas onças de pimenta, duas réstias de alho e duas de cebola, dois alqueires de manteiga, quantidade semelhante de mel e porções não especificadas de sal e vinagre. Por fim a procuração incluía quatro arráteis de cera, ou seja 1,36 quilos, dois afusais de linho, seis cargas de lenha, além de dinheiro. A igreja de São Miguel da mesma vila de Castelo Branco pagava análoga procuração. Vila Velha de Ródão embolsava os mesmos géneros em espécie, não obstante o pão e o vinho serem em menores quantidades ${ }^{64}$.

Como se pode verificar tanto as colheitas do bispado de Coimbra como as do bispado da Guarda apresentam géneros alimentares idênticos. As diferenças residiam sobretudo na quantidade dos géneros, que variaria consoante as disponibilidades locais, e com a ausência de algum produto, como por exemplo o bragal que não estava incluído nas colheitas de Castelo Branco. No que respeita às espécies de carne o tributo de Castelo Branco não se apresentava tão variado com o de Pombal. Ainda assim da análise e comparação destes tributos transparece uma certa uniformidade. Ao estudar as colheitas recebidas pelos bispos não podemos deixar de notar a semelhança com a colheita régia medieval estudada por Iria Gonçalves. Tal como naquela, esta era paga à base de carne, estando ausentes o peixe, o azeite os legumes e a fruta ${ }^{65}$. O peixe consumido principalmente nos "dias magros" não estaria presente numa refeição que se queria ideal. No entanto, sabemos do seu consumo por parte dos prelados no decorrer da visita pastoral. Na visita à freguesia de Santa Eulália de Aveleda, Província de Entre Douro e Minho, Bispado do Porto, Comarca da Maia, termo da cidade do Porto, que teve lugar entre os dias 22 e 24 de Julho de 1748, foi enviado rol ao rendeiro indicando os géneros de que consistiria a procuração, advertindo-se

${ }^{64}$ No bispado da Guarda outras sete igrejas da Ordem de Cristo pagavam procuração, contudo o pagamento era feito em dinheiro, ainda que tenha começado por ser em espécie. Salvaterra do Extremo pagava 29.880 réis, Segura 28.330 réis, Proença-a-Velha 27.410 réis, Idanha-a-Nova 24.010 réis, Marmeleiro e Touro 22.010 réis cada, e Idanha-a-Velha 15.420 réis. As restantes igrejas da Ordem não pagavam procuração por composições antigas que haviam feito com a Mitra, cf. BNP, RP, n. ${ }^{\circ} 498$, tomo I, fls. não numerados.

${ }^{65}$ GONÇALVES, Iria - A Colheita..., cit., p. 178-179. 
que "tudo o que pertence a carne, e aves e prezuntos tudo deve estar na quinta de Santa Cruz, e o peixe na terça seguinte à noite sem falta"66. Entre o peixe constavam 12 pescadas de cabeça grande e "peixe para a meza de Sua Excelencia para cozer e fritar". Relativamente a fruta constavam do rol limões e fruta para a mesa do bispo ${ }^{67}$.

Pelo exposto se verifica que a procuração concedida ao bispo em nada se diferenciou do tipo de alimentos consumidos por indivíduos com recursos económicos semelhantes. Mais se pode acrescentar que estes tributos se mantiveram bastante inalteráveis, chegando ao século XVIII sem reflectir a presença de novos alimentos. Comprovando esta realidade, foi visível a ausência de produtos provenientes do continente americano, os quais constituíram a principal novidade entre a alimentação medieval e a da Época Moderna.

5. A execução das visitas pastorais implicava a deslocação de comitivas, em alguns casos, relativamente extensas. Para sustento e agasalho do séquito, bem como dos animais em que se fazia transportar, foi instituído um tributo, designado procuração ou colheita, que em alguns locais se encontrava taxado. O seu pagamento gerou conflitos, existindo descontentamento de ambas as partes. Os visitandos reclamavam os abusos dos visitadores e das excessivas comitivas que os acompanhavam, negando-se por vezes a pagar o sustento a que estavam obrigados. Por seu turno os visitadores consideravam algumas das colheitas reduzidas. Os textos regulamentadores das visitas pastorais não esqueceram a questão, merecendo particular destaque as constituições do bispado do Porto e as do arcebispado de Braga, nas quais o assunto foi abordado em capítulo particular. As constituições sinodais, os regimentos do auditório, bem como alguns tratados sobre visitações estabeleceram diversos parâmetros a este respeito: comitiva reduzida, obrigatoriedade de o visitador transportar o rol das colheitas, proibição de cobrar mais que uma

${ }^{66}$ BNP, RP 498 I.

${ }^{67}$ Do rol constavam ainda 12 galinhas, 12 frangos, duas arrobas de carne, duas vitelas, dois presuntos, oito arráteis de manteiga de vaca, 10 arráteis de arroz, seis arráteis de açúcar, velas de cera e sebo, vinagre, salsa, cebola, repolhos, ovos, azeite, toucinho gordo, pimenta, cravo-da-índia, dois carros de lenha, pão e vinho, cevada e palha para as bestas, cf. BNP, RP 498 I. 
procuração diária, rejeição de qualquer outro tipo de dádiva, alojamento em casa que não comprometesse o exercício da visita, estabelecimento de penas pecuniárias para os que, estando a isso obrigados, não sustentassem os visitadores.

Entre as colheitas estudadas imperava a carne, estando completamente ausente o peixe, tido na maioria das ocasiões como alimento de substituição. Não obstante, existirem informações de ter sido consumido no decorrer das visitas pastorais. Outras ausências se fizeram sentir tais como o azeite, os legumes e a fruta. As colheitas taxadas parecem ter-se fixado relativamente cedo, mantendo-se inalteradas com o avançar do tempo. Verificou-se que em algumas ocasiões o tributo se transformou numa quantia paga em dinheiro, como sucedeu por exemplo na igreja de Idanha-a-Nova. Além da carne, não podiam faltar ao tributo o pão, o vinho e os ovos, bem como os temperos necessários ao preparo dos repastos. O estudo permitiu verificar uma uniformidade nos produtos que integravam a colheita, sendo que as principais diferenças residiram na quantidade de um ou outro género e na ausência de determinada espécie de carne. Tal coerência apenas poderá significar que a colheita havida pelos prelados, tal como a colheita régia, compreendia os alimentos capazes de proporcionar a refeição ideal. 